\title{
Chronické srdeční selhání - důležité téma pro internisty
}

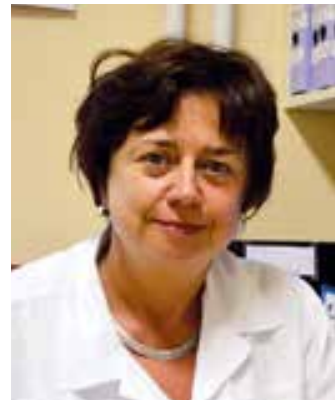

Nemocní s chronickým srdečním selháním (Heart Failure - HF) nejsou pouze v péči kardiologů nebo specializovaných ordinací pro srdeční selhání, které jsou zřizovány na některých velkých pracovištích. Velká část pacientů s HF je diagnostikována během hospitalizace na interních odděleních a interních klinikách nebo v ambulancích internistů, kteři se o ně dále pravidelně starají. Je to právě většinou internista, který v rámci předoperačního vyšetření zjistí u pacienta typické symptomy a známky srdečního selhávání. Proto jsme se rozhodli připravit pro časopis Vnitřní lékařství sérii článků o HF od našich předních odborníků a kardiologů zabývajících se touto problematikou. V tomto čísle se podrobněji seznámíte se základy patofyziologie HF, s moderním algoritmem pro jeho diagnostiku a novinky $v$ léčbě a pozornost je věnována i problematice přidružených nemocí u HF.

Prevalence chronického HF závisí na definici a použitých diagnostických kritériích. Udává se, že se ve vyspělých populacích pohybuje mezi 1-2 \% a výrazně narůstá s věkem. V posledních dekádách se jeho výskyt zvyšuje, nebot' se populace dožívá vyššího věku a paradoxně i úspěšná léčba řady srdečních nemocí přispívá k "dožití se“ srdečního selhání. Příkladem je léčba akutního koronárního syndromu, která je u nás na vysoké úrovni a vede bezprostředně k záchraně života. Tito pacienti se však stávají chronickými pacienty s ischemickou chorobou srdeční (ICHS) a jejich riziko srdečního selhání v průběhu života roste. Podrobně píší o příčinách a epidemiologii srdečního selhání prof. J. Špinar et al ve svém článku.

V květnu 2016 byla publikována nová verze Evropských Doporučení pro diagnostiku a léčbu srdečního selhání [1]. V těchto doporučeních přibyla v diagnostice srdečního selhání nová kategorie zvaná srdeční selhání s ejekční frakcí ve středním pásmu (Heart Failure with mid-range Ejection Fraction - HFmrEF); jedná se o chronické HF u pacientů s ejekční frakcí 40-49\%. V diagnostice HF jsou stanoveny nové hraniční hodnoty natriuretických peptidů; pro BNP $35 \mathrm{pg} / \mathrm{ml}$ a pro NT-proBNP $125 \mathrm{pg} / \mathrm{ml}$, které by se měly prosazovat do každodenní klinické praxe při diagnostice HF. Tyto hraniční hodnoty mají především vysokou negativní prediktivní hodnotu. Novou klasifikaci a současný diagnostický algoritmus pro HF uvádějí ve svém článku MUDr. B. Nussbaumerová et al. Novinky jsou i v léčbě chronického HF, které přehledně zpracoval prof. J. Hradec, který nezapomněl zmínit ani důležitost prevence chronického HF. Úkolem všech lékařư je prevence výskytu chorob. Ne jinak je tomu u chronického HF, které může být projevem poslední fáze jakéhokoliv srdečního onemocnění, ale i nevhodného životního stylu nebo pokročilého věku. Rozvoji srdeční dysfunkce brání zdravý životní styl, účinná léčba hypertenze a ICHS, ale i včasná diagnostika srdečních vad nebo kardiomyopatí́.

Ani přes stálé zlepšování diagnostiky a léčby chronického HF není prognóza pacientů uspokojivá. Mortalita pacientů s HF je vysoká a mnohdy se připodobňuje prognóze pacientů s maligními nádory. Dle současných studií umírá do 1 roku od stanovení diagnózy chronického HF 20 \% pacientů a do 5 let téměř polovina [1]! Př́kladem jsou také naše vlastní výsledky, které jsme získali 3letým sledováním souboru českých pacientů s chronickým HF, který byl v roce 2000 zařazen do evropského projektu EuroHeart Failure Survey. V tomto projektu byla sledována úroveň péče pacientů hospitalizovaných pro chronické HF ve 24 zemích Evropy [2]. Jednou z 6 českých zúčastněných nemocnic byla Fakultní nemocnice Plzeň, další zúčastněné nemocnice byly v Praze a Brně. Český soubor byl i po ukončení evropského projektu dále sledován (v průměru 3 roky) a za pomoci ÚZIS v Praze byla zjištována roční úmrtnost těchto pacientů. Celkem $14 \%$ pacientů zemřelo během hospitalizace a do 12 týdnů od přijetí do nemocnice. Během dalších 3 let zemřelo 36 \% mužů a 42 \% žen s chronickým HF [3].

Pacienti s chronickým HF jsou většinou polymorbidní. Prof. J. Vítovec et al se věnují ve svém článku této velmi důležité problematice, tj. přidruženým onemocněním u pacientů s chronickým HF, a v dalším článku problematice arytmií u pacientů s chronickým HF. Nejčastějšími př́činami, a tedy přidruženými chorobami chronického HF jsou ICHS a hypertenze. Chronické srdeční selhání se vyskytuje častěji u pacientů s diabetem, jehož prevalence (a to především prevalence diabetu 2. typu) výrazně narůstá na celém světě i u nás. Podle provedených studií se chronické HF u diabetiků vyskytuje v 10-30 \% [4]. Pacienti s diabetem mají také častější výskyt hypertenze i ICHS. Tato kombinace chorob je vysoce riziková jak pro rozvoj srdečního selhání, tak pro kardiovaskulární i celkovou mortalitu těchto pacientů. Kombinace makrovaskulárních (aterosklerotických) i mikrovaskulárních komplikací (remodelace arteriol, řídnutí kapilární sítě aj) vedou u diabetiků k velmi závažnému narušení struktury i funkce myokardu. Autonomní neuropatie myokardu vede ke vzniku latentní (němé) ischemie. 
Metabolické poruchy u pacientů s diabetem, především inzulinová rezistence a hyperglykemie, se významně podílejí na poruchách myokardu i bez prítomnosti hypertenze nebo ICHS. Zvýšená glykace proteinů vede $k$ akumulaci jejích produktů (AGE - Advanced Glycation End-products) v cévách i srdci. Vysoká nabídka volných mastných kyselin při inzulinové rezistenci vede $k$ tvorbě triglyceridů a jejich akumulaci v tukové tkáni, $v$ játrech, ale i v myokardu, v němž vzniká tzv. myokardiální steatóza, která se podílí na rozvoji diastolické dysfunkce (dnes nazývané srdeční selhání se zachovalou ejekční frakcí). Zvyšuje se oxidační stres, rozvijí se myokardiální intersticiální i perivaskulární fibróza, je narušena homeostáza kalcia a vzniká řada dalších poruch. Poškození myokardu těmito metabolickými poruchami bez prítomnosti hypertenze a aterosklerózy koronárních tepen se nazývá diabetická kardiomyopatie [5].

Internista bude léčit nemocné s chronickým HF konzervativně, ale měl by vědět, ve kterém okamžiku indikovat speciální prístrojovou léčbu chronického HF a ve kterém okamžiku již pacienta připravovat $k$ transplantaci srdce. Proto je v článcích prof. J. Hradce a prof. L. Špinarové et al věnována pozornost i těmto tématům.

\section{Literatura}

1. Ponikowski P, Voors AA, Anker SD et al. 2016 ESC Guidelines for the diagnosis and treatment of acute and chronic heart failure. The Task Force for the diagnosis and treatment of acute and chronic heart failure of the ESC. Eur Heart J 2016; 18(8): 891-975. Dostupné z DOI: <http://dx.doi. org/10.1002/ejhf.592>.

2. Cleland J, Swedberg K, Cohen-Solal A et al. The Euro Heart Failure Survey of the EUROHEART survey programme. A survey on the quality of care among patients with heart failure in Europe. The Study Group on Diagnosis of the Working Group on Heart Failure of the European Society of Cardiology. The Medicines Evaluation Group Centre for Health Economics University of York. Eur J Heart Fail 2000; 2(2): $123-132$.

3. Rosolova $\mathrm{H}$, Čech J, Šimon J et al. Short to long term mortality of patients admitted with heart failure in the Czech Republic - a report from the EuroHeart Failure Survey. Eur J Heart Fail 2005; 7(5): 780-783. Dostupné z DOI: <http://dx.doi.org/10.1016/j.ejheart.2005.03.009>.

4. Seferovic PE, Petrie MC, Filipatos GS et al. Type 2 diabetes mellitus and Heart failure: a position paper of the European Society of Cardiology Working Group on Cardiovascular Pharmacotherapy. Eur J Heart Fail 2018; 20(5): 853-872. Dostupné z DOI: <http://dx.doi.org/10.1002/ejhf.1170>.

5. Boudina S, Abel E. Diabetic cardiomyopathy revisited. Circulation 2007; 115(25): 3213-3223. Dostupné z DOI: <http://dx.doi.org/10.1161/ CIRCULATIONAHA.106.679597>.

Plzeň, srpen 2018

prof. MUDr. Hana Rosolová, DrSc., FESC

spolueditorka tohoto čísla časopisu Vnitřní lékařství

Centrum preventivní kardiologie II. interní kliniky LF UK a FN PIzeň 